\title{
Field Evaluation of Rhizobium leguminosarum bv. viceae (Rhizobial Strains) Inoculated to Vicia faba L. (faba bean) Cultivars under Nitisol and Chromic Vertisol of Central Highland of Ethiopia
}

\author{
Abere Mnalku \\ Ethiopian Institute of Agricultural Research, P. O. Box: 2003, Addis Ababa, Ethiopia
}

\begin{abstract}
Faba bean varieties and rhizobial strains were tested on two sites of central highland of Ethiopia during the 20162017 cropping season to investigate their interaction effect across years and soil types. The treatments were factorial combinations of three potential varieties of faba bean (Dosha, Moti and Walki) with prospective indigenous rhizobial strains (FBW-145, FB-15 and EAL-110) along with $18 \mathrm{~kg} \mathrm{~N}^{-1}$ and negative control and laid in randomized complete block design (RCBD) with 3 replications. Results showed that strain interaction with variety $(\mathrm{V} \times \mathrm{S})$ could give statistically significant $(\mathrm{P} \leq 0.05)$ and economically profitable grain yield difference at Chiri Nitisol condition. Accordingly, Moti $\times$ EAL-110, Dosha $\times$ FBW-145, Dosha $\times$ EAL-110, and Walki $\times$ FBW145 were the most superior pairs in terms of economic profitability and agronomic productivity at Chiri. Their respective relative grain yields were $45,26,21$, and $16 \%$ and value cost ratios (VCRs) were 101, 66, 44 and 42 , respectively. Year (rainfall amount and distribution, and farm) showed superior nodule number per plant (NNPP), hundred seed weight (HSW) and grain yield change at both soil types. The study generally confirmed that Nitisol of Chiri requires compatible faba bean cultivar and rhizobial strain but not at Vertisol of Kersa Werko.
\end{abstract}

Keywords: Grain yield, Interaction, Rhizobia, Variety

DOI: $10.7176 / \mathrm{JBAH} / 10-18-01$

Publication date:September $30^{\text {th }} 2020$

\section{Introduction}

Faba bean (Vicia faba L.) is the major cool-season grain legume of low-input break crop cultivated in the highlands of Ethiopia and covers $27 \%$ of the total area of pulses and provide $31 \%$ of total pulse production (CSA, 2017). As a grain legume, it provides cheap and quality protein (lysine) supplement (20-40\%) in the cereal- based Ethiopian diet (Nebiyu, 2014), it is gluten free, and also has high index of nutrient density particularly thiamin, niacin, calcium, and iron. Net profit ha ${ }^{-1}$ of faba bean found to be higher than most other pulses and cereals (Yirga et al., 2010). This is attributed to the saving of $150-200 \mathrm{~kg} \mathrm{ha}^{-1}$ of $\mathrm{N}$ as well as some $20-50 \mathrm{~kg}$ in the subsequent crop. Faba bean is the most important grain legume in the highlands of Ethiopia (1800-3000 m) in terms of area, production, foreign exchange earnings, protein source, soil amelioration and nitrogen provision in cropping systems (Giller, 2001; Agegnehu, 2018). The integration of legumes into cropping systems has been recognized to have several advantages. The most important ones are known to be $\mathrm{N}_{2}$-fixation and the control of cereal crop diseases and pests (Graham and Vance, 2000). Legumes are very useful in a crop rotation system that is dominated by cereals, i.e. when cereals are grown after legumes they produce higher protein grains and higher yields than when cereals are grown after cereals (Graham and Vance, 2000; Stagnari et al., 2017).

Faba bean is cultivated predominantly by smallholder farmers and yields are yet low compared to on-farm demos and global outputs due to the use of unimproved local varieties and traditional agronomic practices (Tsgie and Hailemariam, 2006). The use of fertilizer inputs with legumes remains limited in Africa (Chianu et al., 2011). As a result, it has been grown without fertilizer often on nutritionally marginal lands in Ethiopia, with a common notion among farmers that legume crops do not need nutrient inputs. Yet poor legume yields are often a reflection of poor soil fertility (Franke et al., 2016). Thus, the national average grain yields of faba bean is $2.0 \mathrm{t} \mathrm{ha}^{-1}\left(\mathrm{CSA}_{\text {, }}\right.$ 2017).

Faba beans can fix $60-80 \%$ of their nitrogen requirement (Giller, 2001; SPG, 2016), amounting to 60-176 $\mathrm{kg} \mathrm{N} \mathrm{ha}^{-1}$ (Beck et al., 1991) while the average amount of $\mathrm{N}$ fixed in the shoot is estimated to be $129 \mathrm{~kg} \mathrm{ha}^{-1}$ (Peoples et al., 2009). Rhizobial inoculation enhances grain yields of faba bean at different degrees (Mnalku et al., 2016). Preliminary results of faba bean inoculation with effective rhizobia strains in Ethiopia have shown significant dry matter and grain yield improvement (Argaw and Mnalku, 2017).

Legume yields and nitrogen fixation depends on the genotype of the legume $\left(\mathrm{G}_{\mathrm{L}}\right)$, the genotype of Rhizobium strain $\left(\mathrm{G}_{\mathrm{R}}\right)$ and the interactions of these with the bio-physical environment $(\mathrm{E})$, and management practices $(\mathrm{M})$ expressed as the interaction: $\left(G_{L} \times G_{R}\right) \times E \times M$ (Argaw and Muleta, 2017). Response to inoculation, yet is a complex system involving interaction between bacterial genomes, host genomes and the environment. As stated in Laguerr et al. (2003), differences in host plant preference (HPP) for specific rhizobial genotypes within natural populations have been previously reported among these legume genera and species. Report of these authors confirmed the 
existence of HPP for Rhizobium leguminosarum. A strain of Rhizobium creates adequate nodulation in the selected cultivar of the host plant (Appunu et al., 2008). Hence, the relationship between variety and Rhizobium strain is one of the most critical factors influencing symbiotic nitrogen fixation (SNF) (Allito et al., 2015). It is also of paramount importance to determine the best performing varieties and rhzobial strains combination.

Information on the response of the interaction of varities of most legume crops to rhizobial strains is generally inadequate. The information is litraly absent in case of faba bean being the primary grain legume crop in Ethiopia. Therefore, the objective of this study was to investigate the response of selected faba bean varieties to elite rhizobial strains across years and soil types.

\section{Materials and Methods}

\section{Experimental location description}

The experiment was conducted on-farm, over two cropping seasons (2016-2017), at Chiri, and Kersa Werko, locations just to represent the dominant agro-ecologies of the area (Table 1). The locations are found within an elevation range of 1871-2455 meters above sea level. Their mean monthly temperature and monthly rainfall recorded during the effective growing months are indicated on Figure 1. The dominant soils of the locations are also shown in Table 1. The climate of Chiri and Kersa Werko are Tepid to cool moist, and Tepid to cool moist or sub-humid, respectively. Teff (Eragrostis tef), and wheat (Triticum spp.) are the most important cereal crops that grow in these locations (Table 1). Both locations have a mixed farming system with crops and livestock production and grow faba bean in the main rain season (June to August).
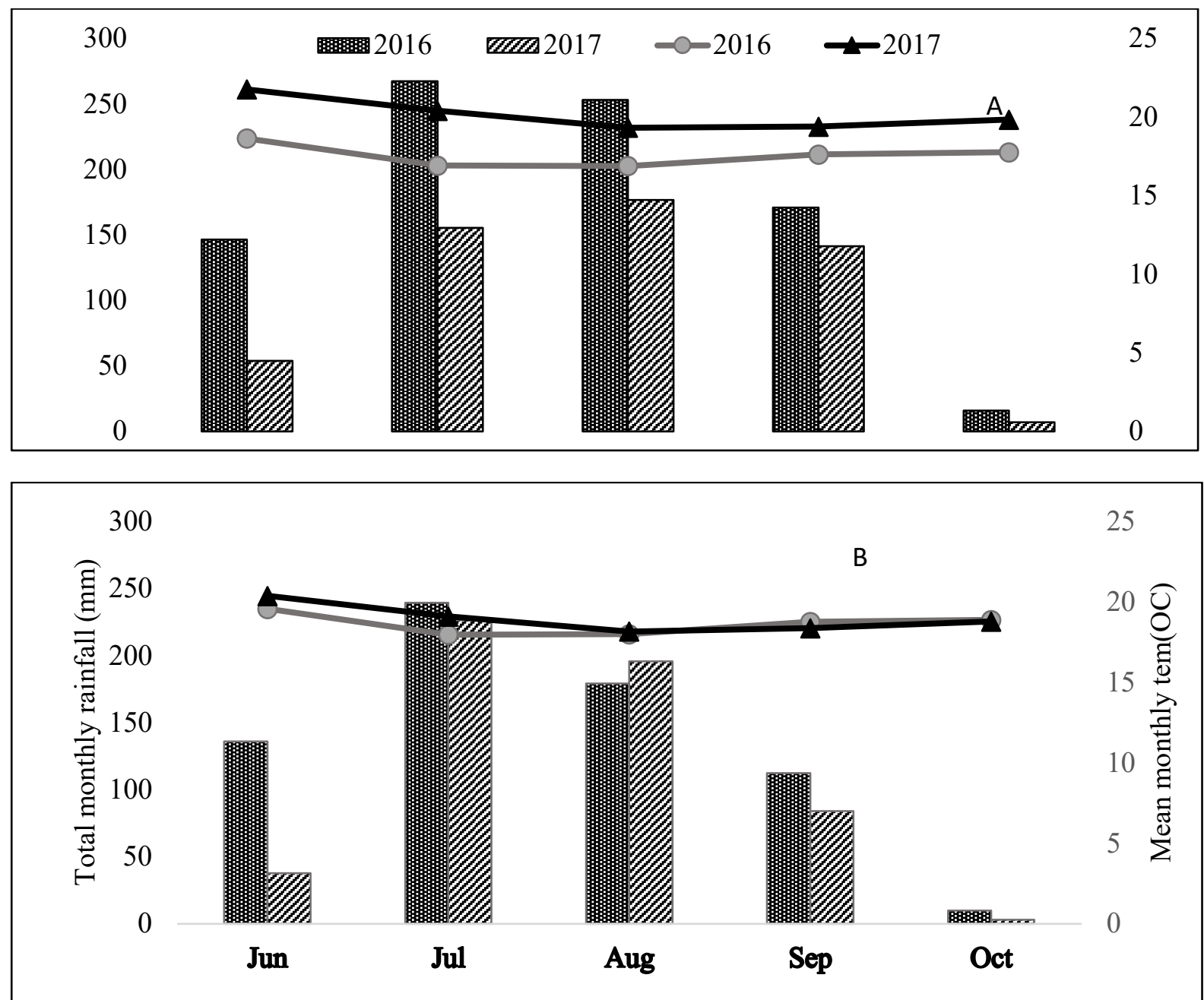

Figure 1. A and B: mean monthly temperature and monthly rainfall records of Kersa Werko and Chiri locations during the experimental periods (Hint: the lines and bars indicate the mean monthly temperature and monthly rainfall, respectively)

\section{Experimental design and treatments}

The treatments of the experiment were factorial combinations of three levels of varieties and five levels of 
inoculants (three strains, one negative control and $18 \mathrm{~kg} \mathrm{~N} \mathrm{ha}^{-1}$ fertilization). The varieties were selected on the basis of their acceptability in the target locations (Table 2). The rhizobial strains were obtained from the elite rhizobia strain evaluation activity, which was carried out during 2015/16 by N2 Africa and Ethiopian Institute of Agricultural Research and designated as FB-15, EAL-110 and FBW-145. The number of treatments was 15 (3*5) and the design used was RCBD in three replications.

The carrier-based rhizobial inoculants were produced using powdered-form of lignite and coated to the seeds following the standard operation procedures indicated in Mitiku et al. (2018). Seeds were sown at rate of $200 \mathrm{~kg}$ $\mathrm{ha}^{-1}$ by maintaining inter-row $(0.4 \mathrm{~m})$ and intra-row $(0.1 \mathrm{~m})$ spacing. Special cares were taken on prior planting of un-inoculated plots and immediate planting of inoculated seeds. Phosphorus was applied in $46 \mathrm{~kg} \mathrm{P}_{2} \mathrm{O}_{5} \mathrm{ha}^{-1}$ in row uniformly to all plots at $10 \mathrm{~cm}$ away from the row in a $2 \mathrm{~cm}$ deep trench and covered after application. The remaining plot management activities were made as per the research recommendations for each location.

Table 1. Agro-ecological characteristics of the study locations

\begin{tabular}{lcc}
\multicolumn{1}{c}{ Biophysical characteristics } & Chiri & Kersa Werko \\
\hline Agro-ecological zone* & Tepid to cool moist & Tepid to cool sub-humid \\
Altitude (meters) & 2441 & 2066 \\
Dominant soil type & Nitisol & Vertisol \\
Major crops & Wheat, teff, faba bean & Wheat, faba bean, teff, chickpea \\
\hline
\end{tabular}

*= Climatic information is obtained from National Meteorology of Ethiopia and Ethiopian Institute of Agricultural Research

Table 2. Varietal characteristics of faba bean used in the on-farm trials from 2016 to 2017 in Ethiopia.

\begin{tabular}{ccccc} 
Variety & Year of release & Maturity period (days) & Adaptable zone (m.a.s.l) & $1^{\mathrm{b}}$ 1000 Seed weight $(\mathrm{g})^{\wedge}$ \\
\cline { 2 - 5 } Dosha* $^{*}$ & 2009 & $120-130$ & $1800-3000$ & 693.3 \\
Moti** $^{2006}$ & $108-165$ & $1800-3000$ & 587 \\
Walki** & 2008 & $133-146$ & $1800-2800$ & 755 \\
\hline
\end{tabular}

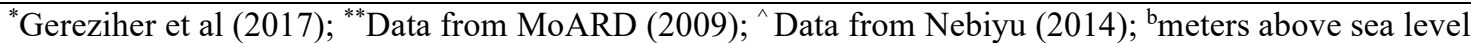

\section{Data management}

Composite soil samples were collected before planting at a depth of $0-20 \mathrm{~cm}$ sampled from 26 even intervals in a "W" pattern from each location. The samples were weighed, air-dried, ground to pass through a $2 \mathrm{~mm}$ sieve for all parameters except soil organic carbon $(0.5 \mathrm{~mm})$ before analysis. Soils were then tested at Holeta Agricultural Research Center laboratory for $\mathrm{pH}$ (1:2.5 soil to $\mathrm{H}_{2} \mathrm{O}$ ), organic $\mathrm{C}$ (Walkley-Black), total N (Kjeldahl), $\mathrm{P}$ (Bray II), following standard laboratory procedures of Sertsu and Bekele (2000). Sampling of plants from $0.5 \mathrm{~m} * 2 \mathrm{~m}$ plot portion was made at 80-90 days after sowing (mid podding) and nodule number per plant was recorded At physiological maturity, harvesting of the aboveground portion was made from inner $6 \mathrm{~m}^{2}$ area and grain yield (GY) data was recorded after being adjusted to moisture content to $11 \%$. Hundred-seed weight (HSW) was also calculated by taking the average weight of 300 seeds from each plot.

The value cost ratio (VCR) was computed using Eq. (1).

$$
\mathrm{VCR}=\frac{\text { Unit price of the produce }\left(\$ \mathrm{~kg}^{-1}\right) *\left[G Y_{T}-G Y_{C}\left(\mathrm{~kg} \mathrm{ha}^{-1}\right)\right]}{\text { Cost of inputs }\left(\$ \mathrm{ha}^{-1}\right)} \ldots \text { Ronner et al. , 2016) }
$$

$\mathrm{GY}_{\mathrm{T}}$ and $\mathrm{GY}_{\mathrm{C}}$ are grain yield of treatment and controls, respectively. Variable cost of control is assumed to be zero. Price of faba bean was obtained from a market survey and set at 0.9 US\$ $\mathrm{kg}^{-1}$. Inoculant price was estimated to be $6.66 \mathrm{US} \$ \mathrm{ha}^{-1}$. Additional labor for the application of inoculants was considered negligible and excluded from the computation.

\section{Statistical analysis}

Before getting into data analysis, data cleaning and missed plot estimation were done and inspection was made if the analysis of variance (ANOVA) assumptions were met. Accordingly, normal distribution and homogeneity of variance of residuals were tested by diagnostic plots generated by PROC UNIVARIATE and PROC GPLOT in SAS-STAT software (SAS Institute, 2008). Nodulation at peak flowering and grain yield traits were subjected to analysis using Linear Mixed Model defined by Piepho et al. (2003):

Response $=\mathrm{V}+\mathrm{S}+\mathrm{V} \times \mathrm{S}: \mathrm{Y} / \mathrm{F}+\mathrm{Y} / \mathrm{F} \times \mathrm{V}+\mathrm{Y} / \mathrm{F} \times \mathrm{S}+\mathrm{Y} / \mathrm{F} \times \mathrm{V} \times \mathrm{S} \ldots \ldots 1$

The model used factors of $\mathrm{V}$, legume host variety; S, strain; Rep, complete replicate; " $\times$ ", notation for interaction; ":", notation precedes random factors and "/", nesting indicator. The effects V, S, and V $\times$ S, were considered fixed while $\mathrm{Y} / \mathrm{F}$, farm nested within season factor was considered to be random factor as seasonal weather is predominantly unpredictable and farms were selected at random. Due to the prevalence of pedoclimatic and biophysical characteristics variability among locations (Table 1), data analysis was made separately. Significance was tested with a type-III-ANOVA. Multiple pairwise comparisons of means were made using the 
MEANS statement with the least significant difference (LSD) test at the $5 \%$ probability level.

\section{Results and Discussion \\ Initial soil}

The summary of soil chemical characterization data is shown in Table 3. Chiri had an average pH of 5.36, which indicated the strongly acidic condition of the soil (Hazelton and Murphy, 2007). Such pH level is common in most faba bean growing areas of Ethiopia where rainfall is high and weathered soils are dominant. Farmers are advised to reclaim such soils with lime if particularly associated with higher exchangeable acidity (Agegnehu et al., 2019). Organic carbon $(\% \mathrm{OC})$ was rated as moderate while $\% \mathrm{TN}$ was medium for both locations and therefore a response to inoculation could be expected as soil $\mathrm{N}$ would not be adequate to support optimal faba bean growth and production. The $\mathrm{C}: \mathrm{N}$ ratios of both locations were between $6.8-10.1$, which is favorable for the decomposition of organic matter.

Table 3. Average soil properties of experimental fields in the two locations

\begin{tabular}{llccccc}
\hline District & $\mathrm{n}$ & $\mathrm{pH}\left(\mathrm{H}_{2} \mathrm{O}\right)$ & $\mathrm{OC}(\%)$ & $\mathrm{TN}(\%)$ & $\mathrm{C}: \mathrm{N}$ & Bray II P $(\mathrm{ppm})$ \\
\hline Kersa Werko & 26 & 6.87 & 1.16 & 0.17 & 6.8 & 12.96 \\
Chiri & 26 & 5.36 & 1.63 & 0.16 & 10.1 & 5.9 \\
\hline
\end{tabular}

$\mathrm{n}=$ sample size; $\mathrm{pH}=$ power of hydrogen; $\mathrm{OC}=$ organic carbon; $\mathrm{TN}=$ Total nitrogen; $\mathrm{C}: \mathrm{N}=$ carbon to nitrogen ratio; $\mathrm{P}=$ phosphorus

The average concentration of available $\mathrm{P}$ was variable across the two locations, unlike other parameters. Chiri had very low $\mathrm{P}$ available rating (0-8 $\mathrm{mg} \mathrm{P} \mathrm{kg}^{-1}$ of soil) (Mallarino et al., 2013). Thus, it would be essential for the farmers to apply external $\mathrm{P}$ source to enhance the performance of both symbionts. Application of $\mathrm{P}$ has been adopted as critical component of rhizobia inoculation of grain legumes in most of Sub-Saharan Africa and worldwide owing to the widespread deficiency of P and its key role in SNF (Vance et al., 2000).

\section{Nodulation}

The interaction of faba bean variety with rhizobial strains $(\mathrm{V} \times \mathrm{S})$ did not produce significant difference $(\mathrm{P} \leq 0.05)$ on nodule number per plant (NNPP) at Chiri and Kersa Werko (Table 4). This confirmed that each of the varieties of faba bean were invariably nodulated by the inoculation of the three strains regardless of location/soil type difference. Similar results were reported on interaction of varieties and rhizobial strains of faba bean by Roskothen (1989), soybean by Tamiru et al. (2012), and pea and lentil by Abi-Ghanem et al. (2011). But, our findings were contrary to those of Argaw and Muleta (2017) who reported significant NNPP difference among Rhizobium inoculants, locations, host genotypes and their interaction on common bean.

In addition, the main effects of rhizobial inoculant and variety were unable to produce significantly different NNPP at both locations (Table 4). This output confirmed that the intended rhizobial strains had similar nodulation capacity with the negative and positive controls. The presence of infective indigenous rhizobia in both soils would have attributed to this effect. However, the main effect of year was able to induce significantly different NNPP at both locations (Table 4). Accordingly, the first year (2016) improved NNPP by 525 and 1514\% at Chiri (Figure 2 ) and Kersa Werko (Figure 3), respectively in comparison to 2017 . The relatively higher rainfall received during July to September in 2016 (Figure 1) would have attributed to this huge nodulation difference. The greater role of rainfall on nodulation of faba bean as compared to soil or variety was reported by Nebiyu (2014).

Table 4. Analysis of variance (ANOVA) of faba bean variety $(\mathrm{V} \times \mathrm{S})$, strain $(\mathrm{S})$, year $(\mathrm{Y})$ and their interactions effect on NNPP, HSW (g) and GY $\left(\mathrm{kg} \mathrm{ha}^{-1}\right)$

\begin{tabular}{|c|c|c|c|c|c|c|c|c|}
\hline Parameters & $\mathrm{V}$ & $\mathrm{S}$ & $Y$ & $\mathrm{~V} \times \mathrm{S}$ & $\mathrm{V} \times \mathrm{Y}$ & $\mathrm{S} \times \mathrm{Y}$ & Grand Mean & CV (\%) \\
\hline \multicolumn{9}{|c|}{ Chiri (2016-2017) } \\
\hline GY (kg/ha) & $*$ & $* * *$ & $* * *$ & $* *$ & ns & ns & 2102 & 12 \\
\hline NN (\#) & ns & ns & $* * *$ & ns & ns & ns & 20 & 28 \\
\hline $\mathrm{HSW}(\mathrm{g})$ & ns & ns & $* * *$ & ns & ns & ns & 59 & 13 \\
\hline \multicolumn{9}{|c|}{ Kersa Werko (2016 - 2017) } \\
\hline GY $\left(\mathrm{kg} \mathrm{ha}^{-1}\right)$ & ns & ns & $* * *$ & ns & ns & ns & 3258 & 18 \\
\hline $\mathrm{NN}(\#)$ & ns & ns & $* * *$ & ns & ns & ns & 28 & 53 \\
\hline $\operatorname{HSW}(\mathrm{g})$ & ns & ns & ns & ns & * & ns & 63 & 14 \\
\hline
\end{tabular}

ns $=$ non-significant at $P<.05 . * * *$ and $* * *$ represent significant difference at $0.05,0.01$ and $0.001 \mathrm{p}$-values. $\mathrm{CV}=$ coefficient of variation.

\section{Hundred seed weight}

Likewise, HSW of faba bean was not significantly $(\mathrm{P} \leq 0.05)$ affected by either the main or interaction effects of strain and variety at both locations (Table 4). Similar results were reported on variety and strain interaction by Tamiru et al. (2012) on soybean and Imran (2015) on chickpea. Degifie and Kiya (2016) also reported nonsignificant different $(\mathrm{P} \leq 0.05) \mathrm{HSW}$ among varieties of chickpea in Gamo-Gofa zone, Ethiopia. However, the 
interaction of variety and year at Kersa Werko and main effect of year at Chiri significantly $(\mathrm{P} \leq 0.05)$ affected HSW (Table 4). Similar to the NNPP, the first year (2016) had an average HSW of $63 \mathrm{~g}$ at Chiri, which surpassed the second year (2017) in $10 \mathrm{~g}$. This result would also be associated with the high amount of rainfall received during the first two months in the location. Moreover, year and site biophysical characteristics appeared to play important role in determining HSW of faba bean (data not shown). Seed weight is influenced by levels of soil fertility and moisture supply (Koldziejek, 2017; Nadew, 2018). The absence of consistently superior or inferior variety across the two locations (data not shown) would indirectly substantiate the importance of environmental variables on HSW as compared to the genetic characteristics of the symbionts.

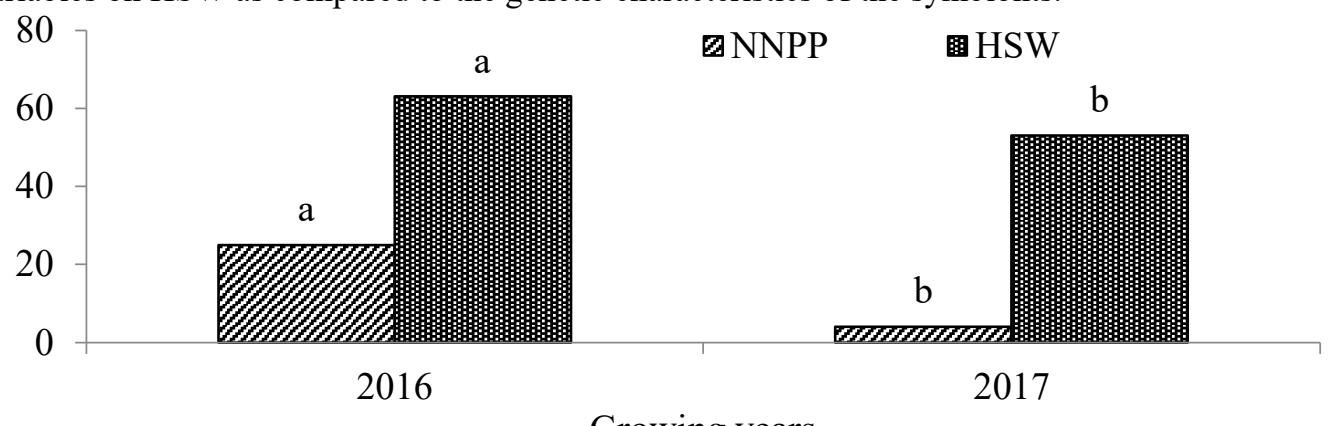

Growing years

Figure 2. Mean of NNPP (\# plant ${ }^{-1}$ ) and HSW (g) recorded during 2016 and 2017 at Chiri; Letters that are different across years within a parameter indicates significant difference at $\mathrm{p} \leq 0.05 .0 .18$ and 4 are the respective LSD values.

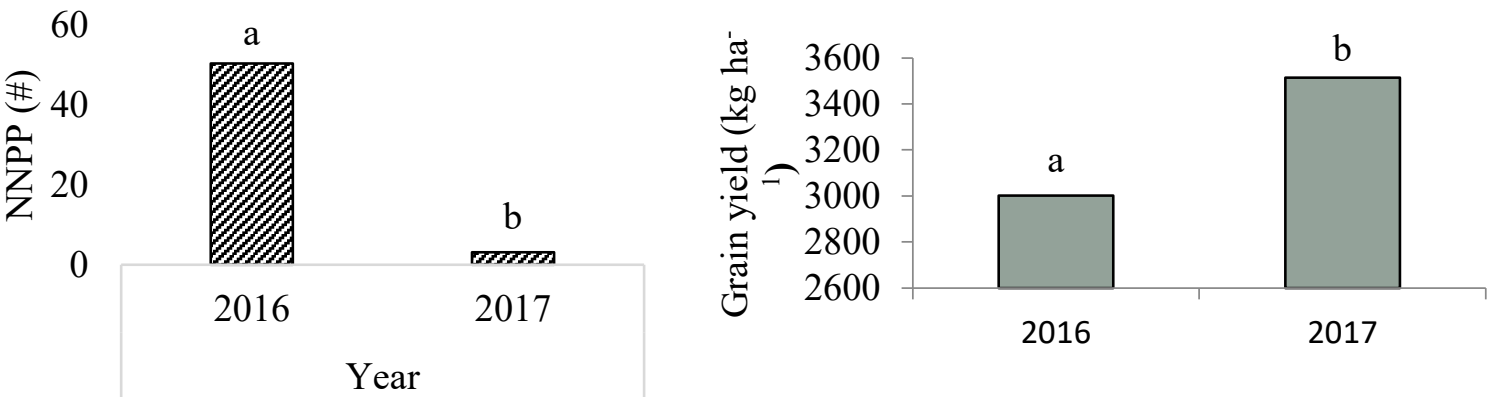

Figure 3. Mean of NNPP (left) and grain yield (right) recorded during 2016 and 2017 at Kersa Werko: Letters that are different across years within a parameter indicates significant difference at $\mathrm{P} \leq 0.05 .0 .18$ and 418 are the respective LSD values

\section{Grain yield}

Unlike NNPP and HSW, the treatments displayed contrasting grain yield performances between the two locations. At Chiri, strain, variety and their interaction effects, and even year depicted significant grain yield difference $(\mathrm{P} \leq$ 0.05) (Table 4). Accordingly, Moti $\times$ EAL-110 was able to produce $2416 \mathrm{~kg} \mathrm{ha}^{-1}$, which is the highest yield for the location despite statistically at par with Dosha $\times$ FBW-145, Dosha $\times$ EAL-110, Walki $\times$ FBW-145, and Dosha $\times \mathrm{N}^{+}$. Similar results were reported on variety and strain interaction by Argaw and Muleta (2017) on common bean and by Imran (2015) on chickpea. Whereas those of Tamiru et al. (2012) and Zimmer et al. (2016) on soybean contradict the current findings at Chiri. Thus, the results demonstrated the need for specific Rhizobium strain development for each of faba bean genotypes when cultivating at Chiri. In other words, grain yield of faba bean varieties were highly determined by the specific strain-host genotypes relationships. It seems reasonable to assume that screening of breeding populations for improvement in $\mathrm{N}$-fixation need to be done with selected effective strain. This specificity could be due to the fact that the exchange of chemical signals (flavonoids and Nod factors) between the two partners are genotype dependent (Long, 2001; Oldroyd and Downie, 2008) and induce the roots nodule formation.

The result obtained at Chiri also depicted significantly different $(\mathrm{P} \leq 0.05)$ grain yield of faba bean among the main effects of variety, year and strain (Table 4). Accordingly, strain EAL-110 and FBW-145 were the first and second top grain yielding and were significantly superior to FB-15 and the controls. Strain EAL-110 gave about 16 and $23 \%$ grain yield improvement over the positive control and the negative control, respectively. Strain FBW-145 also gave about 13 and 20\% grain yield improvement over the positive control and the negative control, respectively. Moreover, the role of year with regards to grain yield determination was clearly substantiated under the current study. Thus, 2016 growing seasons had better grain yield at Chiri and showed about $12.64 \%$ grain yield increment over 2017. The variation in amount and distribution of rainfall (Figure 1) were supposed to 
contribute to this difference.

Table 5. Mean separation of grain yield $(\mathrm{GY})\left(\mathrm{kg} \mathrm{ha}^{-1}\right)$ of interaction $(\mathrm{V} \times \mathrm{S})$, variety and strain main factors during 2016-2017 at Chiri

\begin{tabular}{ll|lc|cccc}
\hline V $\times$ S & GY & Variety & GY & Strains & GY & Year & GY \\
\hline Moti $\times$ EAL-110 & $2416 \mathrm{a}$ & Dosha & $2110 \mathrm{a}$ & EAL-110 & $2273 \mathrm{a}$ & 2016 & $2138 \mathrm{a}$ \\
Dosha $\times$ FBW-145 & $2392 \mathrm{ab}$ & Walki & $2028 \mathrm{ab}$ & FBW-145 & $2211 \mathrm{a}$ & 2017 & $1908 \mathrm{~b}$ \\
Dosha $\times$ EAL-110 & $2296 \mathrm{ab}$ & Moti & $1931 \mathrm{~b}$ & $\mathrm{~N}^{+}$ & $1962 \mathrm{~b}$ & LSD & 114 \\
Walki $\times$ FBW-145 & $2288 \mathrm{ab}$ & LSD & 140 & $\mathrm{~N}^{-}$ & $1849 \mathrm{~b}$ & & \\
Dosha $\times \mathrm{N}^{+}$ & $2115 \mathrm{abc}$ & & & FB-15 & $1821 \mathrm{~b}$ & \\
Walki $\times$ EAL-110 & $2106 \mathrm{bc}$ & & & LSD & 180 & \\
Walki $\times \mathrm{N}^{+}$ & $1983 \mathrm{bcd}$ & & & & & \\
Walki $\times \mathrm{N}^{-}$ & $1975 \mathrm{cde}$ & & & & & \\
Moti $\times$ FBW-145 & $1952 \mathrm{~cd}$ & & & & & \\
Dosha $\times \mathrm{N}^{-}$ & $1902 \mathrm{cde}$ & & & & & \\
Dosha $\times$ FB-15 & $1846 \mathrm{~cd}$ & & & & & \\
Moti $\times$ FB-15 & $1829 \mathrm{~cd}$ & & & & & \\
Walki $\times$ FB-15 & $1789 \mathrm{~d}$ & & & & & \\
Moti $\times \mathrm{N}^{+}$ & $1788 \mathrm{de}$ & & & & & \\
Moti $\times \mathrm{N}^{-}$ & $1671 \mathrm{e}$ & & & & & \\
LSD & & & & & & \\
\hline
\end{tabular}

Letters that are the same within a column are not significantly different at $\mathrm{P} \leq 0.05$. LSD $=$ least significant difference.

As to Kersa Werko, no main and interaction effects showed significant grain yield difference except for the year (growing season). Thus, 2017 was a better grain yielding season and showed about $19 \%$ relative grain yield increment over 2016 (Figure 3). However, the higher nodule bearing year gave the lower grain yield and the viceversa, which confirmed the negative association of the two parameters. It also gave an insight on the hypothesis that higher nodule number would not essentially give better grain yield. Growing season (year) dictated the symbiotic effectiveness of rhizobial strains, which in turn governs grain yield of faba bean regardless of the study locations. Thus, rhizobial screening effort need to be always account for the prevalent rainfall (soil moisture) conditions, which validate the substantial effect of biophysical characteristics of locations on yield of faba bean. According to Nebiyu (2014), location (mainly soil and agro-climatic condition) was found to have a greater influence in determining grain and biomass yield of faba beans.

\section{Value cost ratio of variety and strain interactions}

Like the grain yield responses, the value cost ratios (VCR) of faba bean variety and strain combination treatments were variable across locations (Figure 4). Substantially different degrees of returns were obtained as compared to the respective non-inoculated controls. About $75 \%$ of the combinations were profitable (VCR $\geq 3$ ) at Chiri. The in-situ soil and climatic characteristics of the districts would have direct influence towards this output (Thuita, 2018). Though VCR ratio greater than one indicates profitability of an adopted technology, the break-even point is often not sufficiently attractive Hence, it will be wise to make VCR ratio 3 as a threshold value to determine profitability (Thompson, 1991). Accordingly, except Dosha $\times$ FB-15 and Walki $\times$ FB-15, the remaining pairs were economically profitable. However, Moti $\times$ EAL-110 (the reference combination), Dosha $\times$ FBW-145, Dosha $\times$ EAL-110, and Walki $\times$ FBW-145 were statistically superior and financially rewarding combinations at Chiri. These respective combinations could earn 101, 6644 and 42 units of USD (\$) per every single units of investment in comparison to their uninoculated varieties. Hence, farmers can confidently use these variety-strain combinations for enhancement of faba bean productivity at Chiri where the soil physicochemical properties are similar to those of ours. The use of inoculants was economically very attractive due to the relatively low prices for promotion and a stepwise introduction to smallholder farmers (Ronner et al., 2016). On the other hand, inoculation of either Dosha or Walki with FB-15 strain had poor average economic and agronomic return. 


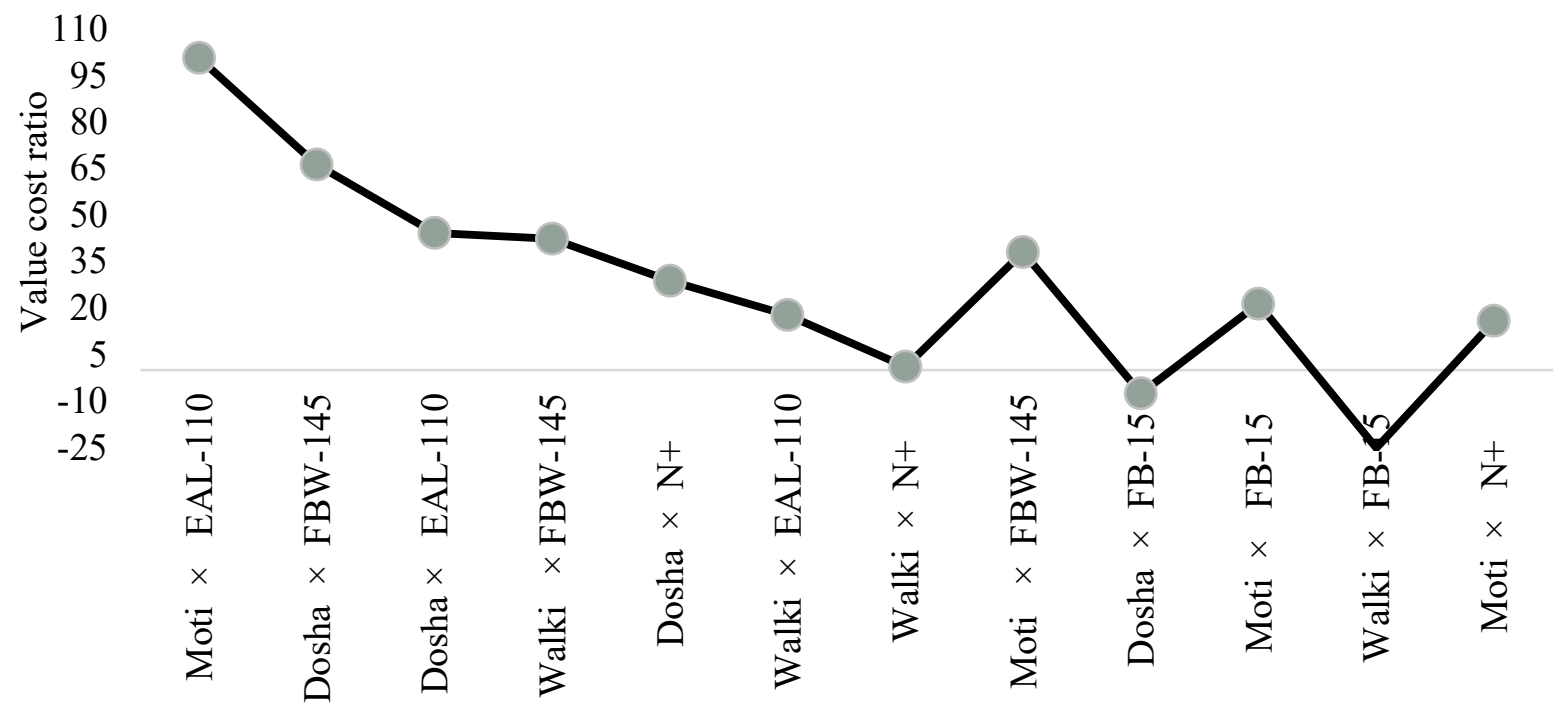

Treatments

Figure 4. Average value cost ratio of the treatments at Chiri (only grain yields were considered on the return side; VCR values $\geq 3$ were considered valuable)

\section{Conclusion}

On-farm trials of faba bean variety and strain interaction were carried out on central Ethiopia. The overall result of the study confirmed the presence of significantly different interaction of the faba bean varieties with the intended rhizobial strains on Chiri Nitisol but not at Kersa Werko Vertisol with respect to grain yield $\left(\mathrm{kg} \mathrm{ha}^{-1}\right)$. The difference would be attributed to the variations in soil characteristics, farm typology and rainfall amount or distribution. Thus growers or researchers at Chiri need to critically look into the choice of more compatible faba bean varieties and rhizobial strains depending on the prevailing rainfall condition. At Kersa Werko, however, selection of better nitrogen fixing variety can be made through exposing single variety to different strains or viseversa. The study generally confirmed that Rhizobium strain and cultivar specificity relied at least on location, strain and cultivar and hence context specific tests would be important.

\section{Acknowledgments}

We thank the Bill and Melinda Gates Foundation for funding through N2Africa-Ethiopia project

\section{References}

Abi-Ghanem R, Carpenter-Boggs L, Smith JL (2011). Cultivar effects on nitrogen fixation in peas and lentils. Biol. Fertil.Soils 47:115-120. doi: 10.1007/s00374-010-0492-6.

Allito B, Nana E, Alemneh A (2015). Rhizobia strain and host-legume interaction effects on nitrogen fixation and yield of grain legume: A Review. Molecular Soil Biology 6(2):1-6. doi: 10.5376/msb.2015.06.0002.

Agegnehu G (2018). Soil fertility and crop management research on cool-season food legumes in the central highlands of ethiopia. Ethiopian Journal of Agricultural Sciences 28:95-109.

Agegnehu G, Chilot Y, Teklu E (2019). Soil acidity management. Ethiopian Institute of Agricultural Research (EIAR). Addis Ababa, Ethiopia. pp.35-52.

Appunu C, Sen D, Singh MK, DH B (2008). Variation in symbiotic performance of Bradyrhizobium japonicum strains and soybean cultivars under field conditions. Journal of Central European Agriculture 9 (1): 185-190.

Argaw A, Mnalku A (2017). Effectiveness of native Rhizobium on nodulation and yield of faba bean (Vicia faba L.) in Eastern Ethiopia. Arch. Agron. Soil Sci. 63:1390-1403. doi: 10.1080/03650340.2017.1287353

Argaw A, and Muleta D (2017). Effect of genotypes-Rhizobium- environment interaction on nodulation and productivity of common bean (Phaseolus vulgaris L.) in eastern Ethiopia. Environ. Syst. Res. 6(14):1-16.

Beck D, Wery J, Saxena M, Ayadi A (1991). Dinitrogen fixation and nitrogen balance in cool-season food legumes. Agronomy Journal 83:334-341.

Chianu JN, Nkonya EM, Mairura FS, Akinnifesi FK (2011). Biological nitrogen fixation and socioeconomic factors for legume production in sub-saharan africa: a review. Agron. Sustain. Dev. 31:139-154. http://link.springer.com/article/10.1051/ agro/2010004. 
CSA (2017). Central Statistis Agency(CSA): Report on area and production of major crops. Agricultural Sample Survey 2013/14, Central Statistical Agency. Volume 1. Addis Ababa, Ethiopia

Degife AZ, Kiya AT (2016). Evaluation of faba bean (Vicia faba L.) varieties for yield at Gircha Research Center, Gamo Gofa zone, Southern Ethiopia. Scholarly Journal of Agricultural Science 6(6):169-176.

Franke AC, Baijukya F, Kantengwa S, Reckling M, Vanlauwe B, Giller KE (2016). Poor farmers-poor yields: socio-economic,soil fertility and crop management indicators affecting climbing bean productivity in Northern Rwanda. Exp. Agric. 1-21. http://dx.doi.org/10.1017/S0014479716000028.

Gereziher T, Ephrem S, Lemma D (2017). Participatory evaluations of faba bean (Vicia faba L.) varieties in Enda Mekoni District, Northern Ethiopia. African Journal of Agriculture 4 (2):263-268.

Giller KE (2001). Nitrogen fixation in tropical cropping systems," Second/Ed. CABI. pp.60-150.

Graham P, Vance C (2000). Nitrogen fixation in perspective: An overview of research and extension needs Field Crops Research 65:93-106.

Hafeez FY,Yasmin S, Airan D, Rahman M, Zafar Y, Malik KA (2006). Plant growth-promoting bacteria as biofertilizer. Agron. Sustain. Dev. 26:143-150. doi:10.1051/agro:2006007.

Hazelton P, Murphy B (2007). Interpreting soil test results: What do all the numbers mean? CSIRO, Collingwood Victoria, Australia.pp.60-85.

Imran A, Muhammad SM, Tariq MS, Kauser AM, Hafeez, FY (2015). Differential response of kabuli and desi chickpea genotypes toward inoculation with PGPR in different soils. Frontiers in Microbiology 6 (859).

Koldziejek J (2017). Effect of seed position and soil nutrients on seed mass, germination and seedling growth in Peucedanum oreoselinum (Apiaceae). Scientific reports 7:1959 DOI:10.1038/s41598-017-02035-1.

Laguerre G, Philippe L, Marie-Reine A, Noe"lle A (2003). Compatibility of rhizobial varietys within natural populations of Rhizobium leguminosarum Biovar viciae for nodulation of host legumes. Applied and Environmental Microbiology 69 (4).

Legesse D, Senait R, Asnake F, Demissie M (2005). Adopting improved chickpea varieties in the central highlands of Ethiopia. Ethiopian Agricultural Research Organization, Report no. 62. pp. 30-42.

Long SR (2001). Genes and signals in the Rhizobium-legume symbiosis. Plant Physiol 125:69-72.

Mallarino AP, Sawyer JE, Barnhart SK (2013). A General guide for crop nutrient and limestone recommendations in Iowa. Department of Agronomy, Iowa State University, Iowa.pp.25-35.

Mnalku A, Heluf G, Fassil A (2009). Symbiotic effectiveness and characterization of Rhizobium strains of faba bean (Vicia Faba L.) collected from Eastern and Western Hararghe Highlands of Ethiopia. Ethiopian Journal of Natural Resources 11 (2): 223-244.

Mnalku A, Yifru A, Getahun M (2016). Response of grain legumes to inorganic and biological fertilizers applications in Ethiopia: A Review. Ethiopian Journal of Natural Resources 16 (1):43-67.

Mitiku G, Mnalku A, Watiti J (2018). Application guideline for rhizobial biofertilizer technologies. Ethiopian Institute of Agricultural Research (EIAR), Addis Ababa, Ethiopia. pp.10-19.

MoARD (2009). Ministry of Agriculture and Rural Development (MoARD): Crop variety register. Issue No. 12. Addis Ababa, Ethiopia.

Nadew BB (2018). Effects of climatic and agronomic factors on yield and quality of bread wheat (Triticum aestivum L.) seed: A Review on Selected Factors. Advances in Crop Science and Technology 6(2):1-5. DOI: $10.4172 / 2329-8863.100035$.

Nebiyu A (2014). Role of faba bean (Vicia faba L.) for intensification of cereal-based cropping systems in the humid highlands of Ethiopia. PhD thesis, Ghent University, Gent, Belgium. p 201.

Oldroyd GE, Downie AJ (2008). Coordinating nodule morphogenesis with rhizobial infection in legumes. Annu Rev Plant Biol. 59:519-546.

Peoples MB, Brockwell DF, Herridge IJ, Rochester BJR, Alves S, Urquiaga RM, Boddey FD, Dakora S, Bhattarai SL, Maskey C, Sampet B, Rerkasem DF, Khans HH, Jensen BS (2009). The contributions of nitrogen-fixing crop legumes to the productivity of agricultural systems. Symbiosis 48:1-17. https://doi.org/10.1007/BF03179980

Piepho HP, Buchse A, Emrich K (2003). A Hitchhiker's guide to mixed models for randomized experiments. J.Agron.Crop Sci. 189: 310-322.

Pypers P, Sanginga JM, Kasereka B, Walangululu M, Vanlauwe B (2011). Increased productivity through integrated soil fertility management in cassava-legume intercropping systems in the highlands of Sud-Kivu, DR Congo. Field Crops Res. 120:76-85.

Ronner E, Franke AC, Vanlauwe B, Dianda M, Edeh E, Ukem B, Bala A, van Heerwaarden J, Giller KE (2016). Understanding variability in soybean yield and response to P-fertilizer and Rhizobium inoculants on farmers' fields in Northern Nigeria. Field Crops Research 186:133-145.

Roskothen P (1989). Genetic effects on host $\times$ strain interaction in the symbiosis of Vicia faba and Rhizobium leguminosarum. Plant Breeding 102(2):122-132.

SAS Institute (2008). SAS/STAT user's guide, version 9.2. SAS Inst. Inc., Cary, NC. USA. 
Sertsu S, Bekele T (2000). Procedures for soil and plant analysis: Technical Paper. Ethiopian Agricultural Research organization (EARO), Addis Ababa, Ethiopia.pp.12-42.

SPG (2016). Saskatchewan Pulse (SPG): Growers Retrieved on April 18, 2019 from: https://saskpulse.com/growing-pulses/faba-beans/seeding/

Stagnari F, Maggio A, Galieni A, Pisante M (2017) Multiple benefits of legumes for agriculture sustainability: an overview Chem. Biol. Technol. Agric. 4(2):1-13.

Tamiru S, Pant LM, Tsige A (2012). Effects of inoculation by Bradyrhizobium japonicum strains on nodulation, nitrogen fixation, and yield of soybean (Glycine max l.merill) varieties on Nitisols of Bako, Western Ethiopia. ISRN Agronomy. doi:10.5402/2012/26147.

Thompsonm A (1991). Australian quality control and standards. In: Thompson, J.A. (Ed.), Expert Consultation on Legume Inoculant Production and Quality Control. FAO, Rome, Italy, pp. 107-111.

Thuita M, Bernard V, Mutegi E, Masso C (2018). Reducing spatial variability of soybean response to rhizobia inoculants in farms of variable soil fertility in Siaya County of western Kenya. Agriculture, Ecosystems and Environment 261:153-160.

Tsige A, Hailemariam A (2006). Biological nitrogen fixation research on food legumes in Ethiopia. in "food and forage legumes of Ethiopia progress and prospects", ICARDA, Addis Ababa, Ethiopia. pp. 172-176.

Vance CP, Graham PH, Allan DL (2000). Biological nitrogen fixation. and phosphorus: a critical future need. In: Pedrosa, F.O., Hungria, M., Yates, M.G., Newton, W.E., Eds., Nitrogen Fixation: From Molecules to Crop Productivity. Kluwer Academic Publishers, Dordrecht, 506-514.

Yirga, C, Shahidur R, Befekadu B, Solomon L (2010). Pulses value chain potential in Ethiopia; Constraints and Opportunities for Enhancing Exports. IFPRI, Addis ababa, Ethiopia.pp.32-41.

Zimmer S, Monika M, Thorsten H, Hans-Peter P, Anke M, Hannes S, Antje H, Frank O, Klaus-Peter W, Jürgen $\mathrm{H}$ (2016). Effects of soybean variety and BradyRhizobium strains on yield, protein content and biological nitrogen fixation under cool growing conditions in Germany. Europ. J. Agronomy 72:38-46. 